\title{
Darwin the Scientist
}

\author{
J. BROWNE \\ Department of the History of Science, Harvard \\ University, Cambridge, Massachusetts 02138 \\ Correspondence: jbrowne@fas.harvard.edu
}

\begin{abstract}
Charles Darwin's experimental investigations show him to have been a superb practical researcher. These skills are often underestimated today when assessing Darwin's achievement in the Origin of Species and his other books. Supported by a private income, he turned his house and gardens into a Victorian equivalent of a modern research station. Darwin participated actively in the exchange of scientific information via letters and much of his research was also carried out through correspondence. Although this research was relatively small scale in practice, it was large scale in intellectual scope. Darwin felt he had a strong desire to understand or explain whatever he observed.
\end{abstract}

During the 2009 Darwin commemorations, scientific researchers and scholars around the world eagerly seized the opportunity to reflect on Charles Darwin's many achievements. As a historical figure, Darwin can mean many things to many people. Most of us carry a particular affection for the young man who sailed in the H.M.S. Beagle and published his account of the voyage in 1839 as Journal of Researches, now a classic text in Victorian travel literature (Darwin 1989). In books, articles, and television documentaries, we have enjoyed catching glimpses of his developing scientific ideas, his incisive comments on the places he visited, and his clear, unaffected prose. Much later on in life, Darwin also wrote a charming autobiography (actually titled by him as Recollections of the Development of My Mind and Character) that has similarly caught the imagination of generations of readers, both inside and outside science. In those recollections, an elderly Darwin looked back over his life and times with generosity and much affection for his friends and family (Barlow 1958). In fact, Darwin left an exceptionally rich documentary record that somehow closes the gap between the centuries. We feel that he was a man we would like to know, someone uniquely special (Fig. 1).

Most of all, in 2009, Charles Darwin is justly celebrated for his magnificent book, On the Origin of Species by Means of Natural Selection, published in London in November 1859 to a storm of controversy (Darwin 1859, 1958). This book made Darwin one of the most prominent naturalists in the world, "first among the scientific men of England," as the socialist philosopher Edward Aveling put it. Even Alfred Russel Wallace, who independently formulated the same idea of evolution by natural selection, said that "Mr. Darwin has given the world a new science, and his name should, in my opinion, stand above that of every philosopher of ancient or modem times." As Wallace predicted, Darwin's ideas came to lie at the heart of fundamental shifts in opinion that swept through the 19th century and beyond (Browne 2002, 2006). The avenues of thought opened up by the theory of evolution by natural selection have guided and provoked research for 150 years. Today, greatly enhanced by the field of genetics and much diversified in intellectual scope, Darwinism stands securely at the cutting edge of scientific knowledge.

Nor do we need reminding that this book excited intense attention, not just for the powerful reach of the proposals, or Darwin's careful analysis of the problem of animal and plant origins, and his weighty accumulation of evidence, but also for the shocking absence-for some people, the liberating absence - of any allusion to the biblical story of creation. Darwin proposed an entirely natural process to explain the characteristics of the living beings that we see around us. This extraordinary combination of features was guaranteed to generate argument in Victorian England. Should God be banished as an explanation for the apparent design and harmony of the world? What should people think about their own origins? Was Darwin suggesting that humans emerged in a natural manner from ape ancestors? These were huge questions that continue to be asked today. On the Origin of Species must surely be regarded as a major publishing event in the 19th century that changed the way that people thought about themselves and helped to lay the foundations of the modern world.

What is less appreciated, even sometimes by biologists, is the range of Darwin's scientific interests-from geology and coral reefs through detailed taxonomic studies of barnacles, human expressions, domestication of plants and animals, to plant physiology. Darwin was a superb experimentalist who designed many effective techniques to probe the natural world. Carried out with simple tools, these experiments provided insights into processes as diverse as the role of earthworms in recycling the land and the movements of climbing plants in their search for support. The anniversary year provides an opportunity to look beyond the continuing uproar over evolution and celebrate Darwin, the practicing scientist. 


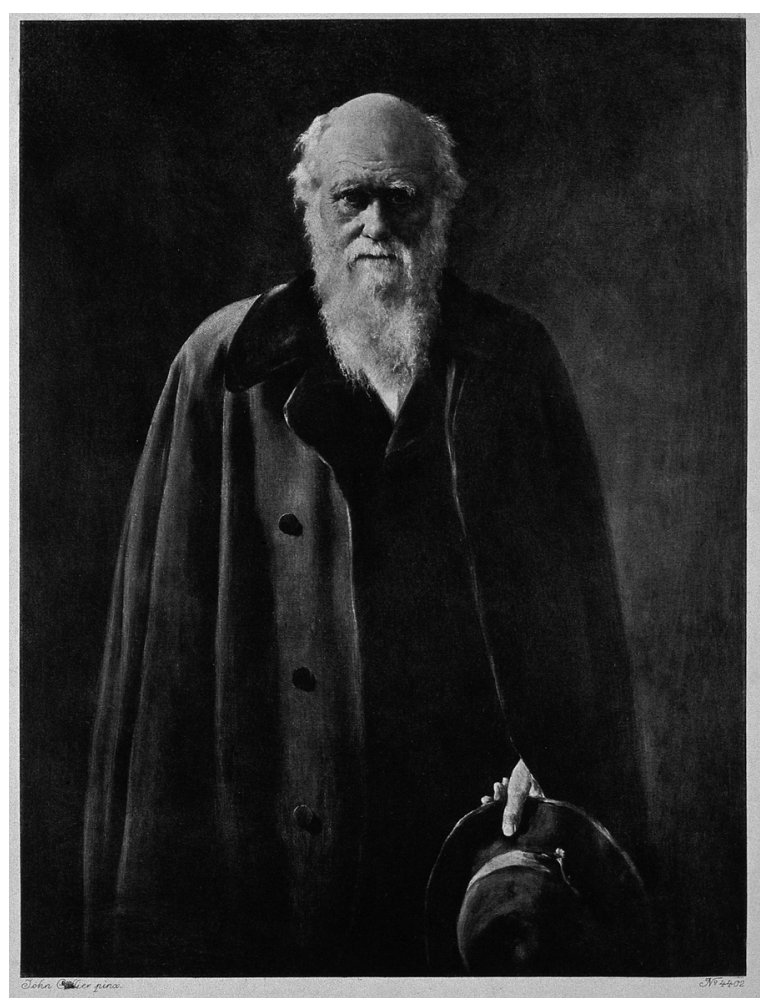

Figure 1. Charles Darwin, in a portrait from life that has become iconic. Photogravure by Leopold Flameng, after the oil portrait by John Collier, 1881. The original hangs in the Linnean Society of London. (Reprinted, with permission, from the Wellcome Library, London.)

\section{CELEBRITY}

Darwin as a scientist often gets lost behind the heat and smoke of the controversy. During his own lifetime, to be sure, he became an icon, one of the first scientific celebrities. That celebrity razzamatazz has a pleasantly old-fashioned air-in those days, the media organization associated with the creation of fame was only just emerging. But there were the makings of a Darwin cult. In the years following publication of the Origin of Species, individuals with a few coins to spare could, if they wished, acquire a pottery statuette of a chimp contemplating a human skull. They could buy any number of photographic cartes de visite featuring Darwin's portrait. If their pockets ran slightly deeper, they could purchase one of a limited edition of portrait photographs of Darwin taken by the society photographer Julia Margaret Cameron and sold by the Bond Street gallery of Colnaghi's, each personally authenticated by the gallery's stamp and by the photographer. Or they might pay to gape at Julia Pastrana, the hairy lady who advertised herself as a "Missing Link," who toured Europe in 1862. British connoisseurs were able to commission an elegant piece of Wedgwood ware decorated with an evolutionary tree. They could sing a duet at the piano on the "Darwinian Theory." Even the agricultural firm of G.W. Merchant, of Lockport, near Rochester, New York, advertised its Gargling Oil with a Darwinian ape that sang:
If I am Darwin's Grandpa,

It follows, don't you see,

That what is good for man \& beast

Is doubly good for me.

All these commercial products made the controversy about human origins fully tangible to Darwin's generation and the ones that followed (Browne 2003).

Darwin was also one of the few scientists to have been portrayed in an extraordinary variety of caricatures. Victorian cartoonists grabbed their chance. “Am I a Man and a Brother?" asked a gorilla in the May 1861 number of the British humorous magazine Punch, echoing the popular perception of Darwin's work (Clark 2009). Although Darwin did not mention human evolution or the likely ancestry of mankind in the Origin of Species, this was the subject that dominated debate after publication. The notorious confrontation between Bishop Samuel Wilberforce and Thomas Henry Huxley at the British Association for the Advancement of Science meeting in Oxford, in June 1860, made the point obvious. The question of whether we are descended from apes or angels quickly became the issue on which Darwin's and Wallace's theories were argued (Browne 2001).

\footnotetext{
Am I satyr or man?

Pray tell me who can,

And settle my place in the scale.

A man in ape's shape,

An anthropoid ape,

Or monkey deprived of his tail?
}

These cultural and social movements indicate strong contemporary interest in the man who was becoming known as the public "face" of evolution. Indeed, few other scientific theories at that time spread as far or as quickly as the theory of evolution by natural selection. Within 10 years of the publication of the Origin of Species, there were 16 different editions in English (including the British Isles and North America), and translations into German, French, Dutch, Italian, Russian, and Swedish, accompanied by important commentaries, criticisms, extracts, and supporting texts by other authors. There would be many more to come. To date, there have been 255 editions in English and translations into 29 other languages, including Turkish, Hindi, Ukrainian, and Yiddish, and one edition in Braille (Freeman 1977). Through these means, people all over the developed world increasingly encountered Darwin's work and were able, if they wished, to participate in what was to become one of the first truly international debates about science.

\section{EXPERIMENTER}

Where, however, is the experimental scientist in all this? Darwin was an active, and often inspired, experimentalist and observational naturalist. Although he worked at home, he turned his house and gardens into a Victorian version of a modern research station. His mind and hands never ceased working. In the years after the Origin of Species was published, Darwin continued at an astonishingly intensive rate. He consolidated the theory 


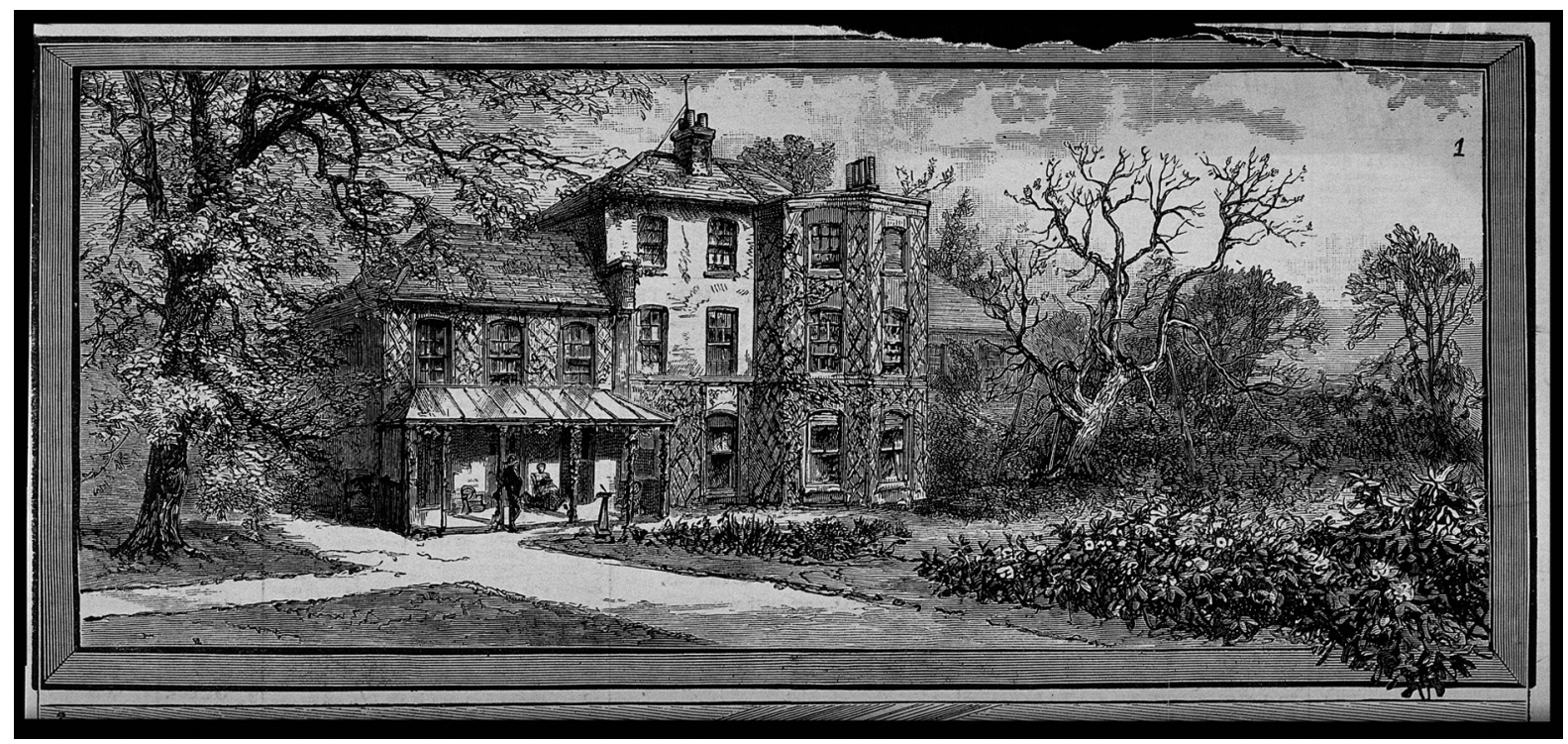

Figure 2. Down House, Darwin's home in Kent for 40 years. (Reprinted, with permission, from the Wellcome Library, London.)

of sexual selection. He devised a theory of inheritance. He explored coadaptation between plants and insects for the purpose of fertilization, experimented on hybrid vigor in plants, documented the animal ancestry of mankind, and thought deeply about the adaptive purposes behind the evolution of the sexes. His major publications after the Origin of Species included an important study of variation under domestication (1868) that showed Darwin discussing heredity, variation, and transmission of what would come to be known as genetic information. He made lasting contributions to the sciences of mankind in his Descent of Man (1871) and the evolution of human expressions in The Expression of Emotions in Man and Animals (1872). His minor publications ranged very widely from seed dispersal to the transmission of ancestral characteristics such as stripes through many generations of horses (van Wyhe 2009).

This is the Darwin who said in his autobiography that he thought he was good at noticing those things that might usually escape attention, and in observing them carefully. He said of himself that he had to learn to be patient in getting results and that a good dose of ambition never did any harm. "From my early youth I have had the strongest desire to understand or explain whatever I observed - that is, to group all facts under some general laws" (Barlow 1958). He was characterizing himself as an experimentalist in an age when laboratories were hardly in existence.

In this regard, Darwin's house was without question his laboratory (Fig. 2). His study was its control center. This study was a scholarly space, but not directly comparable to an academic office. The room was completely domestic, full of an upper middle class Victorian household's furniture, with portraits of the people he most loved and respected above the fireplace, a comfortable chair or two, a red Turkish carpet, even a curtained lobby in a corner that marked off a small area that he used for washing and changing for bed (Fig. 3). There he kept his shaving things (in pre-beard days) and a chamber pot. Yet, in this study, he conducted indoor experiments on plants, worms, and seeds, worked at his microscope, dissected, planned projects, and wrote all his books. His filing shelves were kept beside the chair, his chemical implements and simple microscope close at hand. He did not use a desk. He wrote in a large leather-covered chair, with a board over his knees. Through these years, Darwin was also a family man, a loving father to 10 children, of whom seven reached full adulthood. His space was not entirely sacrosanct. Darwin's children felt able to run in and out of the study to ask for things that might be needed for their games. They sat on the wheeled stool, used by their father as his microscope seat, and punted themselves about the room with Darwin's walking stick. It was the room where Darwin spent so many years studying barnacles under the microscope that one of his sons, when a very little boy visiting another child to play, innocently asked where does your father do his barnacles (Darwin 1887 [1: 136]).

It was also the room from which Darwin ran his entire research and publishing ventures. Although Darwin did not actively engage in public debate, much preferring that quick-witted friends such as Thomas Henry Huxley should carry his theories into the eye of the storm, he nevertheless participated directly through correspondence. There are some 14,500 letters to and from Darwin still in existence, mostly housed in the University Library Cambridge, UK, and the American Philosophical Society in Philadelphia, that show the extent of Darwin's networks across the globe and the manner in which he used letters, on the one hand, to collect information and, on the other hand, as strategy to promote his views (Burkhardt et al. 1985). Current research into the history of Darwin's achievement, and the manner in which his views came generally to prevail, shows that he actively embedded himself in a web of correspondence that materially advanced the reception of his work. 


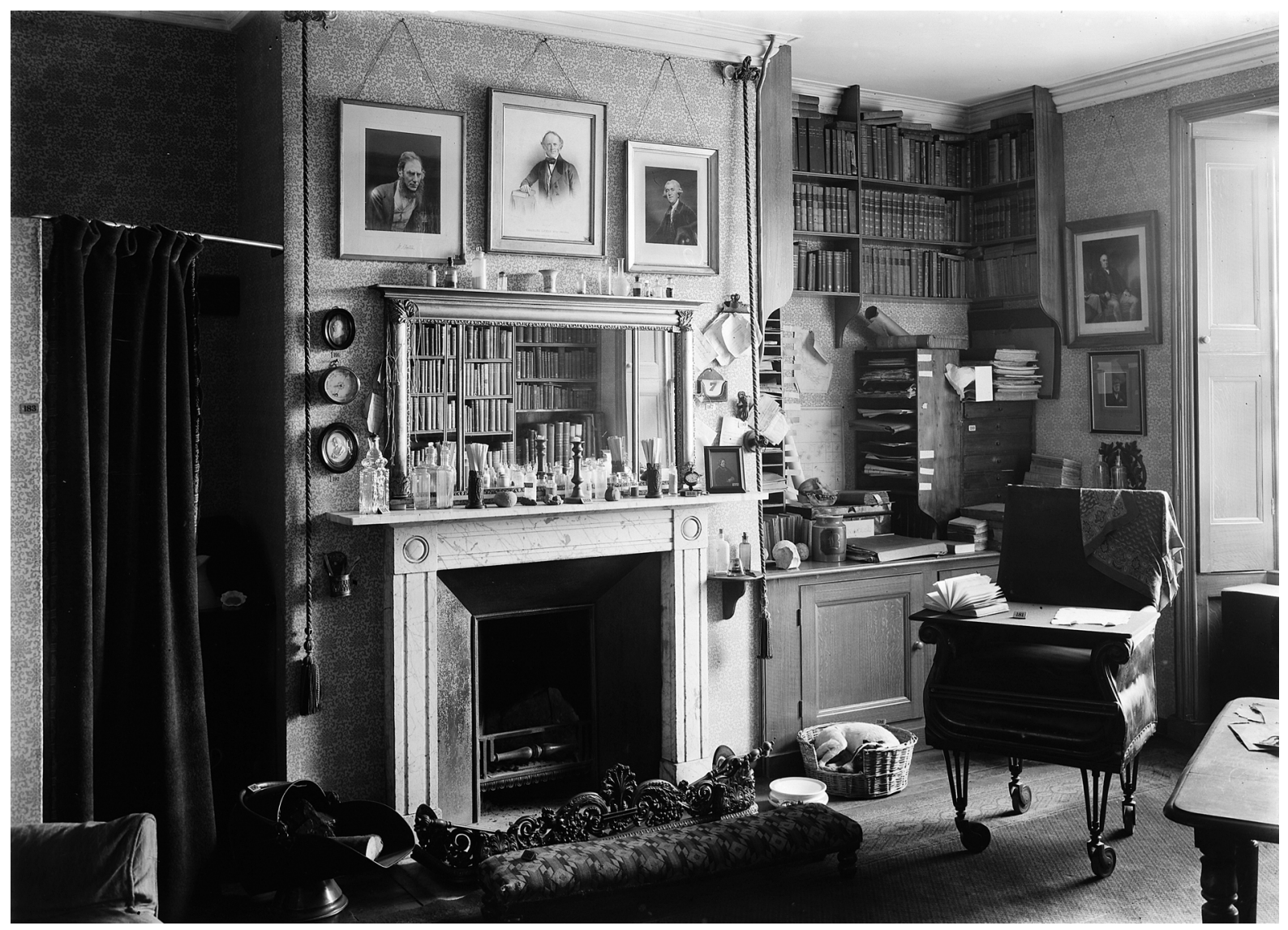

Figure 3. Darwin's study. He used this room from 1842 to 1881 . From a photograph taken after the opening of the house as a museum in 1929. (Reprinted, with permission, from the Wellcome Library, London.)

We may feel that letter writing was only to be expected in the 19th century. But it is useful to think of the world of Victorian correspondence as a major vehicle for scientific communication, in which experimental results were systematically circulated, proposals were assessed, conclusions were modified, and responses were gauged. Before the rise of the scientific periodical - the journal Nature was founded in 1869-it was customary to keep up to date through loosely structured correspondence networks. Of course, many scientific periodicals existed in the 19th century that served a diverse range of audiences (Cantor and Shuttleworth 2004). But recent studies suggest that research was, at that time, mostly published in books or in the transactions of learned societies. It is only since the early 20 th century that scholarly journals have come to be seen as the primary place to publish. Hence, an exchange of letters was essential scientific procedure for Victorians like Darwin. At that time, too, there was not the same clear-cut dividing line between public and private, as there is now, and much "publication" took place in letters to various correspondents. One striking aspect of this pattern of 19 th century communication remains today in the convention that journals such as Nature still publish important new results in a "letter" to the editor. Darwin keenly awaited letters every day, and he fixed a small mirror to the inside of his study window so that he could see the postman turning up the drive.

\section{WORK AS DAILY LIFE}

It is therefore possible to regard Darwin's working practices as an intensified form of daily life. He was fortunate to be privately wealthy and had no need to obtain paid employment. The research on which he based the Origin of Species reflected this world of personal wealth and privilege: a world of gentleman landowners who were sufficiently well financed and well educated to relish a few experiments in horticulture or land economy; a world in which plentiful correspondence was a vital link to contemporary opinion; a world of stability and prosperity where the advantages brought by rapid industrialization were subtly in evidence in the countryside (Desmond and Moore 1991; Browne 1995, 2002). Darwin's botanical and animal experiments were carried out in his own stable yard, greenhouse, or garden. He used ordinary organisms easily procured from the catalogs of nurserymen or through gentleman farmers. Any book research relied on his subscriptions to private libraries or his membership of the elite scientific societies of London. Occasionally, he yearned to acquire exotic species, and this yearning was a prime reason for Darwin's first 
exchange of letters with Alfred Russel Wallace in Malaysia in 1856 (Burkhardt et al. 1985 [vol. 6, letter to W.B. Tegetmeier, 26 November 1856]). Later, much of his botanical correspondence was dominated by the urge to obtain rare orchids or carnivorous plants for experimentation. Joseph Hooker at the Royal Botanic Gardens, Kew (in London) was a loyal friend, for example, and often supplied interesting materials from the government glasshouses. On one occasion, Darwin was distressed to realize that he had inadvertently destroyed a valuable Oxalis sent to him by Hooker for research into the "sleep" of plants. His was a highly domestic research environment. Investigations into the "fixity" of pigeon and poultry breeds turned into an admiration for the birds as pets. The family's dogs became the object of close observation when he began exploring animal expressions and emotions.

The point is worth emphasizing because it was partly this reliance on commonplace features of Victorian lifeletters and small-scale experimental inquiries involving relatively accessible animals and plants - that generated the remarkable body of factual material on which the Origin of Species rests. Darwin took a certain pride in this ordinariness. Yet, we can retrospectively see something special. When compiling a chapter of recollections of his father for The Life and Letters of Charles Darwin (1887), his son Francis recorded that

it was as though he [Darwin] were charged with theorising power ready to flow into any channel on the slightest disturbance, so that no fact, however small, could avoid releasing a stream of theory, and thus the fact became magnified into importance. In this way it naturally happened that many untenable theories occurred to him; but fortunately his richness of imagination was equalled by his power of judging and condemning the thoughts that occurred to him. He was just to his theories, and did not condemn them unheard; and so it happened that he was willing to test what would seem to most people not at all worth testing (Darwin 1887 [1: 149]).

He also favored ingenuity and frugality. When the French naturalist Alphonse de Candolle visited Darwin at home in the 1870s, he found the author of the Origin of Species pottering around his greenhouse working on carnivorous plants with almost no tools except his schoolboy chemical balance and some tin plant markers. All the experimental chemicals that Darwin used in order to discern the power of plant digestion came from around the house-ammonia, beer, urine, spittle, and nicotine. Experimental plants were bedded out in the kitchen garden and parts of the lawn were sectioned off for recording the number of species able to grow in a demarcated area. Such observations always ran hand in hand with hard thinking. Every day, Darwin would take a number of circuits around what he called his thinking path, the "Sandwalk," to ponder whichever question was uppermost in his mind at the time.

Darwin did not work alone. A prominent characteristic of these projects was the help he requested from friends, relatives, and even enemies. His children became assistants from an early age. Darwin usually spent the summer months researching insect pollination, for example, and might use the veil of his wife's hat to cover a particular plant. Or he could spend several hours a day closely watching ants or worms. At age five, his son Leonard ran to a garden flower and cried "I've got a fact to do"- neat encapsulation of the way that Darwin's work was the focus of the household. The household staff was also accustomed to furthering their master's researches.

Indoors, Darwin's wife Emma often acted as his amanuensis, copying out sections of the Origin of Species before publication, as well as other works, and helping with his correspondence when he was unwell. Emma Darwin read the proof sheets of the Origin of Species, a sure sign that her religious beliefs were not holding Darwin back in any pragmatic sense. Later, when their daughter Henrietta was older, she acted as an editor for Darwin by going over his proof sheets for style. This female assistance is often ignored by historians (Harvey 2009). The proof sheets amended by Henrietta are now preserved in the Cambridge archive and we can see her comments in the margins: "this is a horrid sentence." Henrietta corrected the proof sheets of the Descent of Man for her father, who was so grateful that he sent her a substantial gift of money. All of the family were involved in his work in one way or another. Even the children's governess was prevailed upon to translate some difficult German biological tracts. In this manner, Darwin's researches became a family enterprise. He was one of the last gentlemen of science with sufficient private income to work at home, outside the developing academic institutions.

\section{A TALENT TO EXPERIMENT}

Francis Darwin was convinced that much of his father's talent lay in his urge to observe things for himself:

There was one quality of mind which seemed to be of special and extreme advantage in leading him to make discoveries. It was the power of never letting exceptions pass unnoticed. Everybody notices a fact as an exception when it is striking or frequent, but he had a special instinct for arresting an exception. . . . Another quality which was shown in his experimental work, was his power of sticking to a subject; he used almost to apologise for his patience, saying that he could not bear to be beaten, as if this were rather a sign of weakness on his part. He often quoted the saying, "It's dogged as does it;", and I think doggedness expresses his frame of mind almost better than perseverance. Perseverance seems hardly to express his almost fierce desire to force the truth to reveal itself. (Darwin 1887 [1: 148,149])

The most important work Darwin did after the Origin of Species was undoubtedly that relating to human beings (Desmond and Moore 2009). During the Beagle voyage and beyond, he had made extensive notes on humankind, asking himself penetrating questions about physical and cultural anthropology, the mental and moral life of humans, metaphysics, history, and demography. During the 1860s and 1870 s, he thoroughly reviewed these materials and expanded their scope dramatically. His preparatory research for the Descent of Man (1871) brought his concept of sex- 
ual selection to full development and required extensive documentation in the animal kingdom before he felt confident in applying it to explain the origin of human diversity (Darwin 2004). In that book, he drew on correspondence with anthropologists and travelers the world over to discuss the differences and similarities among humans. One objective was to show that the attributes of human beings could have derived from those of animals, and he corresponded widely about the origins of language, religious belief, and the moral sense in order to gather evidence that animals possessed similar traits to a lesser degree.

The following year, he brought out his book on the Expression of the Emotions (1872), a crucial follow-up to the Descent of Man. In this, he continued to argue for real links between humans and animals by documenting the mental life of human beings and suggesting that the facial musculature, and by implication the emotions underneath, could be connected with those of our presumed animal ancestors (Darwin 1988, 2009). This book required a huge international research project that called on artists and photographers as well as anthropologists. One element of research support came from the many female members of the extended Darwin family who made personal observations for him on their children. Darwin also observed his own children very carefully when they were babies, having no conceptual problem in comparing them to the baby orangutan that he saw in the London Zoo (Keynes 2001).

Time after time, he searched out appropriate people to help him. Oscar Reilander, the Swedish art photographer, lived in London and participated in Darwin's research. Reilander was a pioneer in composite photography and eager to experiment with different techniques for Darwin. He photographed himself mimicking the exaggerated emotional expressions used by actors on the London stage, several of which Darwin reproduced in the resulting book. In one composite image forwarded to Darwin, Reilander pictured himself laughing in one shot and expressing sorrow in the other, a piece of early technical wizardry to facilitate comparison of the musculature that was not pursued in detail until much later in the century (Prodger 2009).

Yet however ingenious, Darwin's experiments were relatively small scale. The point was made with a sting when Francis Darwin went in 1875 to Württemberg to work with the great plant physiologist Julius Sachs. Sachs had the most advanced laboratory in Europe, filled with expensive physiological apparatus that made Francis envious. His father was not convinced that they needed any of these instruments for their researches back at Down House, although he did allow Francis to buy a Zeiss microscope that is still in the Darwin museum. On his return from Sachs' laboratory, Francis pursued a new line of investigation into the movements of plant roots and shoots, and he showed his father how to improvise smoked paper on a rotating drum by fastening a small cylinder on an open clock face. When their joint book on the Power of Movement in Plants (1880) was published, Sachs savagely criticized the results by claiming that work done in a country house simply could not match the new experimental results emanating from a laboratory (de
Chadarevian 1996). Darwin was irritated, to say the least. Nevertheless, some of his proposals about tropisms were proved to be correct in the 1920s and 1930s.

\section{CONCLUSION}

What can be made of all this activity? In a year of celebration and commemoration, it is apt to praise Darwin as a magnificent and perceptive theorist and as a gifted writer. We can come to see him as someone who lived and worked in an intellectually vigorous social network rather than as a solitary heroic individual. We can admire his modesty, succinctly reflected in a few words written to Huxley at the height of the debate about the Origin of Species: "I wish I could feel all was deserved by me."

But it is also good to remember his ability to connect observation with theory, his persistence, ambition, and good humor, all excellent qualities to foster in modern laboratory practice. He was a fine experimental scientist. Writing after a visit to Darwin's home in 1878, the British journalist Edmund Yates felt sure that he had been in the presence of a very great investigative mind:

Without an atom of scientific jealousy, he is always ready to expound his views, to narrate the result of the delicate experiments on which he is perpetually occupied, and to assist other investigators from the stores of an experience that has ranged over the whole field of natural science, and the conclusions of a mind trained to reason closely on such facts as have been ascertained by actual observation. No naturalist of this or any other time has confined himself more strictly to well-ascertained facts, and devoted more labour to original investigation. The reason of this excessive care is to be found in the keystone of the Darwinian philosophy - La vérité quand même; the pursuit of truth through all difficulties, and without regard to consequences (Hodgson 1878 [p. 224]).

\section{REFERENCES}

Barlow N, Ed. 1958. The autobiography of Charles Darwin 1809 1882 (with original omissions restored. Edited with appendix and notes by his granddaughter Nora Barlow). Collins, London. Browne EJ. 1995. Charles Darwin: Voyaging, Vol 1 of a biography. Knopf, New York.

Browne EJ. 2001. Darwin in caricature: A study in the popularisation and dissemination of evolution. Proc Am Philos Soc 145: 496-509.

Browne EJ. 2002. Charles Darwin: The power of place, $\mathrm{Vol} 2$ of a biography. Knopf, New York.

Browne EJ. 2003. Charles Darwin as a celebrity. Sci Context 16: 175-194.

Browne EJ. 2006. Charles Darwin's Origin of Species: A biography. Atlantic, London.

Burkhardt FH, Smith S, et al., Eds. 1985-. The correspondence of Charles Darwin (16 volumes). Cambridge University Press, Cambridge.

Cantor GN, Shuttleworth S, Eds. 2004. Science serialized: Representation of the sciences in nineteenth-century periodicals. MIT Press, Cambridge, Massachusetts.

Clark CA. 2009. "You are here": Missing links, chains of being, and the language of cartoons. Isis 100: 571-589.

Darwin CR. 1859. On the origin of species by means of natural selection, or the preservation of favoured races in the struggle for life. Murray, London. 
Darwin F, Ed. 1887. The life and letters of Charles Darwin, including an autobiographical chapter, 3 volumes. Murray, London.

Darwin CR. 1958. On the origin of species: A facsimile of the first edition (with an Introduction by Ernst Mayr). Harvard University Press, Cambridge, Massachusetts.

Darwin CR. 1988. The expression of the emotions in man and animals (3rd edition, with Introduction, Afterwords, and Commentaries by Paul Ekman). Harper Collins, New York.

Darwin CR. 1989. Charles Darwin's journal of researches (1839) (ed. with an Introduction by J Browne and M Neve). Penguin, London.

Darwin CR. 2004. The descent of man, and selection in relation to sex (edited and with an Introduction by James Moore and Adrian Desmond). Penguin, London.

Darwin CR. 2009. Expression of emotions in man and animals (ed. J Cain and S Messenger). Penguin, London.

de Chadarevian S. 1996. Laboratory science versus country-house experiments. The controversy between Julius Sachs and
Charles Darwin. Br J Hist Sci 29: 17-41.

Desmond AJ, Moore JR. 1991. Darwin. Michael Joseph, London.

Desmond AJ, Moore JR. 2009. Darwin's sacred cause. Allen Lane, London.

Freeman RB. 1977. The works of Charles Darwin: An annotated bibliographical handlist, 2nd ed. Dawson, Folkestone, United Kingdom.

Harvey J. 2009. Darwin's “angels": The women correspondents of Charles Darwin. Intellect Hist Rev 19: 197-210.

Keynes R. 2001. Annie's box: Charles Darwin, his daughter and human evolution. Fourth Estate, London.

Prodger P. 2009. Darwin's camera: Art and photography in the theory of evolution. Oxford University Press, New York.

van Wyhe J. 2009. Charles Darwin's shorter publications, 1829 1883. Cambridge University Press, Cambridge.

Yates EH. 1878. Mr. Darwin at Down. Celebrities at home. The World, 223-230. www.darwin-online.org.uk. 


\section{$\$_{\mathrm{CSH}}^{\infty} \mathrm{C}$ Cold Spring Harbor Symposia SYMPOSIA on Quantitative Biology}

\section{Darwin the Scientist}

J. Browne

Cold Spring Harb Symp Quant Biol 2009 74: 1-7 originally published online May 27, 2010 Access the most recent version at doi:10.1101/sqb.2009.74.047

\section{License}

Email Alerting Receive free email alerts when new articles cite this article - sign up in the box at the Service top right corner of the article or click here. 